\title{
CRIMES AGAINST HUMANITY IN THE WORKS OF THE INTERNATIONAL LAW COMMISSION ON THE DRAFT ARTICLES ON THE PREVENTION AND PUNISHMENT OF CRIMES AGAINST HUMANITY
}

\begin{abstract}
Crimes against humanity, besides war crimes, belong to the most frequently committed and prosecuted crimes of international law. Recently, the International Law Commission adopted draft Articles on the prevention and punishment of crimes against humanity, bridging the gap in international criminal law and in international cooperation between states. When discussing the draft Articles on the prevention and punishment of crimes against humanity, the International Law Commission did not act in a vacuum. The issue of understanding crimes against humanity and the obligations of states related to the prevention and punishment of these crimes has appeared in the works of the Commission since the 1950s, primarily in connection with the development of the draft Code of crimes against the peace and security of mankind and the statute of the International Criminal Court. Based on its previous experiences, the International Law Commission focused on four issues to be covered by the draft Articles: 1) definition of crimes against humanity; 2) the obligation of states to criminalise such crimes in domestic law; 3 ) the obligation of states to cooperate in the investigation, prosecution and punishment of these
\end{abstract}

* Ph.D., Faculty of Law and Administration, Cardinal Stefan Wyszyński University, Warsaw 
offences; 4) the duty of aut dedere aut judicare fortified by the perpetrator's stay in the territory of the state party. Considering the broad support for the definition of crimes against humanity adopted in the ICC Statute and its complementary character, the International Law Commission adopted the definition of art. 7 of the ICC Statute. The works of the International Law Commission are focused on the obligations of countries related to prevention and punishment of crimes against humanity, especially: the obligation to criminalise crimes against humanity and to establish jurisdiction over those crimes. The International Law Commission also formulated a series of obligations of states with a procedural character in the draft Articles, for example, obligation to conduct prompt and efficient criminal proceedings, the purpose of which is to explain all the circumstances of the crime and to punish the guilty person or persons.

Keywords: crimes against humanity, duress and necessity, genocide, international and hybrid criminal tribunals, International Criminal Court, International Criminal Tribunal for the Former Yugoslavia, International Criminal Tribunal for Rwanda, International Law Commission, International Military Tribunal, International Military Tribunal for the Far East, ICC Statut, Special Court for Sierra Leone, Special Panels for East Timor, UN Commission on War Crimes, universal jurisdiction, war crimes

\section{Introduction}

In 2019, the International Law Commission adopted, in the second reading, a draft of articles on the prevention and punishment of crimes against humanity. This initiative of the International Law Commission began work on regulating one of the most serious and most common crimes of international law. Crimes against humanity, in contrast to genocide and war crimes, are not subject to a multilateral international convention requiring states to take preventive measures and criminalise them. Hitherto, efforts of the international community have focused on judging and punishing just penalties to the perpetrators of these crimes at the international level, pushing to the background issues related to the prevention of these crimes, inter-state cooperation or the obligation of states to criminalise these crimes in domestic law. Primarily, criminal responsibility for crimes against humanity is currently carried out on the international level by numerous international and hybrid criminal 
tribunals. The jurisdiction of none of these tribunals is exclusive and does not exclude the participation of the state and its law enforcement bodies in accounting for these crimes of international law. The tasks of states and their judicial systems, related to bringing international criminals to account, are underlined by the Statute of the International Criminal Court, adopted in Rome on 17.7.1998. ${ }^{1}$ In the preamble of the ICC Statute, states confirmed that the most serious international crimes cannot remain unpunished and that effective prosecution must be ensured by taking appropriate action, both by individual states and by strengthening international cooperation. In the preamble, the States Parties also recalled that it is the duty of each state to exercise criminal jurisdiction over persons responsible for the crimes of international law. The ICC Statute is neither an international criminal code nor a set of rules defining international criminal proceedings. It does neither replace national criminal legislation nor does it replace states with their duty to ensure and exercise jurisdiction over crimes against humanity. ${ }^{2}$ However, the ICC Statute stresses the twofold duty of states related to crimes against humanity, i.e. the exercise by the domestic courts of criminal jurisdiction over persons accused of these crimes and obligations related to inter-state cooperation.

While international and hybrid criminal tribunals implement international justice regarding the most serious perpetrators of crimes against humanity, the acts constituting these tribunals do not contain legal norms defining specific obligations of states in preventing and punishing crimes against humanity. Meanwhile, the prevention and punishment of crimes against humanity raises a lot of questions ranging from understanding crimes against humanity and the associated obligation to criminalise such crimes by domestic law, by indicating the rules for exercising jurisdiction by national courts over persons accused of such crimes, to specific duties related to inter-state cooperation.

The subject of this article is to discuss the work of the International Law Commission on the draft articles on the prevention and punishment of crimes against humanity. The genesis of the Commission's work, including historical background, will be discussed in the first part of the article. The current works of the International Law Commission are

Rome Statute of the International Criminal Court, 17.7.1998, UNTS vol. 2187.

2 J. Stigen, The Relationship between the International Criminal Court and National Jurisdictions. The Principle of Complementarity, Martinus Nijhoff Publishers, Leiden 2008, p. 2. 
not carried out in a vacuum, and crimes against humanity were the subject of the Commission's deliberations in the course of work on other issues, in particular on the draft code of crimes against the peace and security of mankind and on the statute of the International Criminal Court. The next chapter will present the current state of work on the draft of articles, and the key provisions adopted by the Commission will be discussed. In the summary, prospects for the future will be presented.

\section{Genesis of the starting works of the International Law Commission on the draft articles on the prevention and punishment of crimes against humanity}

Nowadays, crimes against humanity, next to war crimes, belong to the most frequently committed and prosecuted crimes of international law. ${ }^{3}$ In many humanitarian crises, especially in non-international armed conflicts, there are serious violations of human rights and international humanitarian law that do not fall within the category of genocide (e.g. due to the lack of dolus coloratus, and therefore the intention to destroy, in whole or in part, a specific community) or war crimes (because, for example, they were committed in situations of tension and unrest that are not considered armed conflict). Crimes against humanity have been and are the subject of the work of all international and hybrid criminal tribunals that have been operating since 1991. In the doctrine of international law, the first two ad hoc criminal tribunals for the former Yugoslavia and for Rwanda were described as courts for crimes against humanity. ${ }^{4}$ Crimes against humanity have also become the basis for the operation of subsequently appointed hybrid criminal tribunals, i.e. the Special Court for Sierra Leone ${ }^{5}$

3 G. H. Stanton, Why the World Needs an International Convention on Crimes Against Humanity [in:] L.N. Sadat, 'Forging a Convention for Crimes Against Humanity', Cambridge University Press, Cambridge 2011, pp. 355-356.

4 G. Sluiter, "Chapeau Elements" of Crimes Against Humanity in the Jurisprudence of the UN Ad Hoc Tribunals, [in:] L.N. Sadat, 'Forging a Convention for Crimes Against Humanity’, Cambridge University Press, Cambridge 2011, p. 103.

5 Agreement between The United Nations and The Government of Sierra Leone on the establishment of a Special Court for Sierra Leone, 16.1.2002, UNTS vol. 2178. 
and the Cambodian Tribunal. ${ }^{6}$ It is worth noting that both hybrid tribunals dealt primarily with crimes against humanity, and in each case, the courts settled criminal responsibility for committing crimes against humanity.

The adoption of a universal convention on the prevention and punishment of crimes against humanity should therefore contribute to harmonisation at a national level of the definition of these crimes and the provisions ensuring effective prosecution and punishment. From the beginning of the work of the International Law Commission on the draft articles on the prevention and punishment of crimes against humanity, both the Special Rapporteur and the Commission took the position that the starting point should be the definition of crimes against humanity contained in Article 7 of the ICC Statute. This understanding of crimes against humanity received the widest support among the states and also reduces the fragmentation of international criminal law and promotes the enhancement of the complementary nature of the jurisdiction of the International Criminal Court. ${ }^{7}$

The basic function of the principle of complementarity is to determine the relationship between the jurisdiction of the international court and the national judicial authorities. As Mohamed M. El Zeidy notes, "ICC is intended to supplement the domestic punishment of international violations rather than supplant domestic enforcement of international norms". This principle also indirectly implies an obligation to criminalise crimes against humanity (and other crimes of international law falling under the jurisdiction of an international court) at the level of national law. According to Article 17(1) of the ICC Statute, which indicates the criteria for admissibility of jurisdiction by the ICC, the Court shall determine that the case is inadmissible, amongst others, when the case has been investigated in the state which has jurisdiction over it, and the state has decided not to prosecute the suspect, unless the decision resulted from the unwillingness or inability of that state genuinely to prosecute. If, therefore, the criminal prosecuting bodies classified as an ordinary crime

6 Agreement between The United Nations and The Royal Government of Cambodia concerning the prosecution under Cambodian law of crimes committed during the period of Democratic Kampuchea, 6.6.2003, UNTS vol. 2329.

7 First report on crimes against humanity, by Sean D. Murphy, Special Rapporteur, 17.02.2015, A/CN. 4/680, paras. 121-122; Report of the International Law Commission, Sixty-seventh session (4.5.-5.6.2015 and 6.7.-7.8.2015), p. 60.

8 M.M. El Zeidy, The Principle of Complementarity in International Criminal Law: Origin, Development and Practice, Brill, Leiden-Boston 2008, pp. 157-158. 
an act which, in light of the ICC statutes, could be regarded as a crime against humanity, not indulging in this way its entire lawlessness, the Court's competence resulting from the principle of complementarity would be updated. Lack of national rules, properly criminalising crimes against humanity, could be considered as the inability of this state to actually prosecute these crimes. ${ }^{9}$

The principle of complementarity cannot and should not replace the treaty norm obliging the state to criminalise crimes against humanity in domestic law. In addition, neither treaty rules nor customary international law specify the rules for the exercise of jurisdiction over these crimes by the states, including universal jurisdiction or the principle of aut dedere aut iudicare. ${ }^{10}$ The 1968 convention on the non-application of a statute of limitations for war crimes and crimes against humanity in Article III obliges states to adopt all internal measures necessary to enable the extradition of persons suspected of crimes, while Article IV of this convention obliges states to take any legislative or other measures necessary to ensure that the statute of limitations is not applied in the prosecution and punishment of these crimes. ${ }^{11}$ These regulations establish crimes against humanity as extraditable offense, but neither obligate states to prosecute perpetrators of these crimes based on universal jurisdiction nor obligate states - in the absence of extradition - to carry out criminal proceedings. ${ }^{12}$ This convention also does not indicate situations in which the duty to prosecute crimes against humanity by the state would be updated. The duty to criminalise and prosecute based on universal jurisdiction, however, results from the 1973 convention on suppression and punishment of the crimes of apartheid ${ }^{13}$ and from the convention from 1984 against torture and other cruel, inhuman or degrading treatment or

9 Ibidem, p. 205.

10 P. Akhavan, The Universal Repression of Crimes Against Humanity before National Jurisdictions. The Need for a Treaty-Based Obligation to Prosecute, [in:] L.N. Sadat, 'Forging a Convention for Crimes Against Humanity', Cambridge University Press, Cambridge 2011, p. 36.

11 Convention on the non-applicability of statutory limitations to war crimes and crimes against humanity, 26.11.1970, UNTS vol. 754, p. 73.

12 P. Akhavan, The Universal..., p. 32.

13 International Convention on the Suppression and Punishment of the Crime of Apartheid, 30.11.1973, UNTS vol. 1015. 
punishment. ${ }^{14}$ Both treatises, however, formulate the principle of universal jurisdiction only with regard to the acts covered by them and not to crimes against humanity.

A clear answer to the question of the principle of universal jurisdiction is not provided by international customary law. ${ }^{15}$ In the doctrine of international law, there are voices claiming that states are obliged to investigate crimes against humanity founded on the principle of universal jurisdiction based on international custom. T. Ostropolski is in favour of accepting the universal jurisdiction of crimes against humanity. ${ }^{16} \mathrm{M}$. Cherif Bassiouni also thinks that crimes against humanity are universally condemned, and international law makes them a duty of universal jurisdiction. ${ }^{17}$ However, it is not possible to derive from international customs other rules for the exercise of national jurisdiction against crimes against humanity, including the principle of territoriality, the personal principle and the protective principle.

\section{Crimes against humanity in the past works of the International Law Commission}

When discussing the Draft Articles on the prevention and punishment of crimes against humanity, the International Law Commission did not act in a vacuum. The issue of understanding crimes against humanity and the obligations of states related to the prevention and punishment of these crimes has appeared in the works of the Commission since the 1950s, primarily in connection with the development of the draft Code of crimes against the peace and security of mankind and the statute of the International Criminal Court. Both of these legal acts concern

14 Convention against Torture and Other Cruel, Inhuman or Degrading Treatment or Punishment, 10.12.1984, UNTS vol. 1465.

15 P. Akhavan, The Universal..., p. 40.

16 T. Ostropolski, Zasada jurysdykcji uniwersalnej $w$ prawie międzynarodowym [The principle of universal jurisdiction in international law], Instytut Wydawniczy Euro Prawo, Warszawa 2008, p. 81.

17 M. Cherif Bassiouni, Universal Jurisdiction for International Crimes: Historical Perspectives and Contemporary Practice, [in:] M. Cherif Bassiouni (ed.), 'International Criminal Law Third Edition, vol. II, Multilateral and Bilateral Enforcement Mechanisms', Brill, Leiden 2008, pp. 125-126. 
the prosecution of crimes against humanity at an international level and relate these crimes to international criminal responsibility. However, during the work on these documents, such issues were raised: the exercise of jurisdiction by the state over individuals accused of committing crimes, the obligation of states aut dedere aut iudicare, minimum procedural safeguards for persons accused of a crime, the ne bis in idem principle and the lex retro non agit principle. In addition, the work of the International Law Commission on the draft Code of crimes against the peace and security of mankind and the statute of the International Criminal Court are extremely important in the context of the definition of crimes against humanity.

\subsection{Works of the International Law Commission on the draft Code of crimes against the peace and security of mankind}

The first work on the elaboration of a draft Code of crimes against the peace and security of mankind was taken by International Law Commission in 1949, when Jean Spiropoulos was appointed the Special Rapporteur for this topic. Until 1954, the Commission became acquainted with three reports of the Special Rapporteur and the comments on the draft submitted by states. ${ }^{18}$ The draft Code of Crime of 1954 contained 5 articles, the first of which introduced the general rule of individual criminal responsibility, and Article 2 contained a catalogue of acts deemed to be crimes against the peace and security of mankind and defined them. Further provisions introduced the principle of irrelevance of the public function and acting on the order for criminal responsibility (Articles 3 and 4 of the draft) and announced the creation of a court competent to inflict appropriate penalties on the perpetrators of crimes (Article 5 of the draft). Although Article 2 did not call any of the acts crimes against the peace and security of mankind, Article 2 point (10) of the project used the term of inhumane

18 Draft Code of Crimes Against the Peace and Security of Mankind - Report by J. Spiropoulos, Special Rapporteur, Yearbook of the International Law Commission 1950, vol. II, pp. 253-277; Second Report on the Draft Code of Crimes Against the Peace and Security of Mankind by Mr. J. Spiropoulos, Special Rapporteur, Yearbook of the International Law Commission 1951, vol. II, pp. 43-69; Third Report on the Draft Code of Crimes Against the Peace and Security of Mankind by Mr. J. Spiropoulos, Special Rapporteur, 'Yearbook of the International Law Commission' 1954, vol. II, pp. 112-123. 
acts committed by state authorities or by private persons against civilians. ${ }^{19}$ The International Law Commission in the Commentary to the draft Code stated that Article 2 point (10) was the equivalent of Article 6 point (c) of The Charter of the International Military Tribunal, which defined crimes against humanity. ${ }^{20}$ The first draft Code, apart from the indirect definition of crimes against humanity, did not therefore contain any regulation affecting international obligations of states in the field of prevention of crimes against humanity, criminalising these crimes in national law or rules for the exercise of jurisdiction over persons accused of these crimes.

After reviewing the draft Code of crimes against the peace and security of mankind, the UN General Assembly decided that the issues dealt within the Code are closely associated with the definition of aggression, and further work on the project should be postponed until that definition is developed. ${ }^{21}$ In practice, this meant the postponement of further work on the draft Code for decades, and the UN General Assembly returned to this subject only in 1981. ${ }^{22}$ Between 1982 and 1991, Special Rapporteur Doudou Thiam presented nine reports on a draft Code of crimes against the peace and security of mankind. ${ }^{23}$ The first two reports concerned the evolution of the codification of international criminal law, the scope of subjective

19 Draft Code of Crimes against the Peace and Security of Mankind, 'Yearbook of the International Law Commission' 1954, vol. II, pp. 140-173.

20 Ibidem.

21 A/RES/897(IX), 4.12.1954.

22 A/RES/36/106, 10.12.1981.

23 First Report on the Draft Code of Crimes Against the Peace and Security of Mankind, 'Yearbook of the International Law Commission' 1983, vol. II (Part One), A/CN.4/364, p. 137; Second Report on the Draft Code of Crimes Against the Peace and Security of Mankind, 'Yearbook of the International Law Commission' 1984, vol. II (Part One), A/CN.4/377, p. 89; Third Report on the Draft Code of Crimes Against the Peace and Security of Mankind, 'Yearbook of the International Law Commission' 1985, vol. II (Part One), A/CN.4/387, p. 63; Fourth Report on the Draft Code of Crimes Against the Peace and Security of Mankind, 'Yearbook of the International Law Commission' 1986, vol. II (Part One), A/CN.4/398, p. 53; Fifth Report on the Draft Code of Crimes Against the Peace and Security of Mankind, 'Yearbook of the International Law Commission' 1987, vol. II (Part One), A/CN.4/404, p. 1; Sixth Report on the Draft Code of Crimes Against the Peace and Security of Mankind, 'Yearbook of the International Law Commission' 1983, vol. II (Part One), A/CN.4/411, p. 197; Seventh Report on the Draft Code of Crimes Against the Peace and Security of Mankind, 'Yearbook of the International Law Commission' 1989, vol. II (Part One), A/CN.4/419, p. 81; Eighth Report on the Draft Code of Crimes Against the Peace and Security of Mankind, 'Yearbook of the International Law Commission' 1990, vol. II (Part One), A/CN.4/430, p. 27; Ninth Report on the Draft Code 
and objective codification, as well as the methodology of the draft Code and its implementation. Subsequent reports of the Special Rapporteur were devoted to particular crimes recognised as crimes against the peace and security of mankind. The fourth and seventh reports of the Special Rapporteur were devoted to crimes against humanity.

The fourth report of the Special Rapporteur, presented in 1986, included genocide within the meaning of crimes against humanity within the framework of the Convention of 9.12.1948 on the Prevention and Punishment of the Crime of Genocide ${ }^{24}$ and apartheid within the meaning of the Convention of 30.11 .1973 on suppression and punishment of the crimes of apartheid. In addition, crimes against humanity include inhuman acts, such as murder, extermination, slavery, displacement or persecution committed against social, political, racial, religious or cultural constituencies, as well as other serious violations of international obligations that are important for security or preservation of the natural environment of mankind.$^{25}$ In the seventh report, the Special Rapporteur extended the description of crimes against humanity for slavery and all other forms of serfdom, including forced labour, expulsion or forced resettlement of territory, development of settlements in occupied territories and changes in the demographic composition of foreign territory. The Special Rapporteur introduced changes in the understanding of inhuman acts, including mass destruction of property belonging to the population. ${ }^{26}$

The definition of crimes against humanity proposed by the Special Rapporteur was therefore broader than that of crimes against humanity resulting from the Agreement for the Prosecution and Punishment of the Major War Criminals of the European Axis, to which the Statute of the International Military Tribunal ${ }^{27}$ was attached, and from

of Crimes Against the Peace and Security of Mankind, 'Yearbook of the International Law Commission' 1991, vol. II (Part One), A/CN.4/435, p. 37.

24 Convention on the Non-Applicability of Statutory Limitations to War Crimes and Crimes Against Humanity, 26.11.1968, UNTS vol. 754.

${ }^{25}$ Fourth Report on the Draft Code of Crimes Against the Peace and Security of Mankind, 'Yearbook of the International Law Commission' 1986, vol. II (Part One), A/CN.4/398, pp. 85-86.

${ }^{26}$ Seventh Report on the Draft Code of Crimes Against the Peace and Security of Mankind, 'Yearbook of the International Law Commission' 1989, vol. II (Part One), A/CN.4/419, pp. 85-86.

27 Agreement for the Prosecution and Punishment of the Major War Criminals of the European Axis, and Charter of the International Military Tribunal, London, 
the Convention on the Non-Applicability of Statutory Limitations to War Crimes and Crimes Against Humanity. Both treaties show that crimes against humanity include: (a) murder, extermination, turning people into slaves, deportation and other inhumane acts that were committed against any civilian population or persecution for political, racial or religious reasons; (b) displacement due to armed attack or occupation; (c) inhumane acts resulting from the apartheid policy; (d) genocide.

The definition of crimes against humanity proposed by the Special Rapporteur in the fourth report also recognised as crimes against humanity other serious violations of international obligations that are important to the safety or preservation of the human environment. Thus, the Special Rapporteur included into the definition of crimes against humanity not only the behaviour codified by international law, but also those behaviours that are an expression of the gradual development of international law to the extent that it involved offenses against the environment. ${ }^{28}$ In this way, the Special Rapporteur referred to the concept of international crimes of states, presented in the Draft Articles of the International Law Commission on the responsibility of states from $1976 .{ }^{29}$ Article 19(3)(d) of the Draft Articles on the responsibility of states regarded as a crime of international law a serious violation of international obligations of vital importance for the protection and preservation of the environment, such as large-scale atmospheric or sea pollution. It is also worth noting that genocide was included in the scope of crimes against humanity, which was an expression of the postulates of some of the doctrine of international law. ${ }^{30}$ The inclusion of apartheid in the scope of the crime in question should be positively assessed, thus ensuring consistency of the definition of crimes against humanity with the Convention on combating and punishing the crimes of apartheid, which recognised apartheid as a crime against humanity, giving birth to international responsibility. The proposal

8.8.1945 [in:] D. Schindler, J. Toman, 'The Laws of Armed Conflicts', Martinus Nijhoff Publishers, Dordrecht 1988, pp. 912-919.

${ }^{28}$ Fourth Report on the Draft Code of Crimes Against the Peace and Security of Mankind, 'Yearbook of the International Law Commission' 1986, vol. II (Part One), A/CN.4/398, p. 61.

29 Ibidem.

30 Report of the International Law Commission on the work of its twenty-eighth session, 3.5.-23.7.1976, Official Records of the General Assembly, Thirty-first session, Supplement No. 10, 'Yearbook of the International Law Commission' 1976 vol. II (2), pp. 95-96. 
of the Special Rapporteur also finally rejected linking crimes against humanity with armed conflict and other crimes, recognising crimes against humanity as independent crimes.

During 43 sessions in 1991, the International Law Commission adopted a draft Code of crime against the peace and security of mankind. ${ }^{31}$ This draft, however, did not use the term crimes against humanity, while Articles 19-21 dealt consecutively with genocide, the crime of apartheid and systematic or mass violations of human rights. Understanding of genocide and apartheid was based on - being in force in international relations - the convention of 1948 on the prevention and punishment of the crime of genocide and of 1973 on combating and punishing the crimes of apartheid ${ }^{32}$. On the other hand, systematic or mass violations of human rights were understood as murder, torture, establishing or maintaining over persons a status of slavery, servitude or forced labour, persecution on social, political, racial, religious or cultural grounds in a systematic manner or on a mass scale or deportation or forcible transfer of population ${ }^{33}$. According to the Commission's commentary, this definition was based on the draft Code of crimes against the peace and security of mankind of 1954 and was supplemented by the development of international law that had been the result of the past decades. The adoption by ILC of systematic or mass violations of human rights was related to the perception of crimes against humanity as a collective category involving various serious violations of human rights and international humanitarian law, including genocide and apartheid and other crimes committed during armed conflict. At the same time, proposing the recognition of certain violations of human rights as a crime against the peace and security of humanity, the Commission emphasised two features of these violations, i.e. a systematic and large-scale character. Systematic or large-scale violations of human rights included those crimes against humanity that were neither genocide nor the crime of apartheid, nor were they within the scope of war crimes, but at the same time were so serious that the international community had an interest in prosecution and judgment.

31 Report of the International Law Commission on the work of its forty-third session, ILC Report, A/46/10, (F), 1991, chap. IV paras. 60-176.

32 Ibidem, pp. 102-103.

33 Ibidem. 
The draft Code of crime against the peace and security of mankind has been handed over to states to allow them to submit their observations. ${ }^{34}$ Comments on Article 21 were reported by Australia, Austria, Brazil, Bulgaria, the United States of America, Paraguay and the United Kingdom. Finally, after hearing that comments and the thirteenth report of the Special Rapporteur ${ }^{35}$, the International Law Commission adopted in its second reading in 1996 the final text of the draft Code of crimes against the peace and security of mankind. ${ }^{36}$ The project consisted of 20 articles divided into two parts, the first part of which formulated the principles of responsibility for crimes covered by the project, while the second part listed and defined individual crimes.

Among the principles of criminal liability, the draft Code included an obligation for states to exercise jurisdiction over persons accused of committing crimes against humanity regardless of the jurisdiction of the International Criminal Court and regardless of where and by whom the crime was committed (Article 8), the obligation to issue or punishing the perpetrator of the crime (Article 9 and 10), the principle of ne bis in idem (Article 12), the principle of non-retroactivity (Article 13) and the principle of taking account of attenuating circumstances when punishing (Article 14).

The draft Code includes, apart from the crimes of aggression, genocide, crimes against the United Nations and associated personnel and war crimes, crimes against humanity (Article 18). However, while earlier proposals did not express the crimes against humanity, finally adopted in 1996, the draft Code of Crimes Against the Peace and Security of Mankind clearly uses this term. In the final version of the draft Code, crimes against humanity were defined as any of the following acts, when committed in a systematic manner or on a large scale and instigated or directed by a government or by any organisation or group: (a) murder; (b) extermination; (c) torture; (d) enslavement; (e) persecution on political, racial, religious or ethnic grounds; (f) institutionalised discrimination on racial, ethnic or religious grounds involving the violation of fundamental human rights and freedoms and resulting in seriously disadvantaging

34 Ibidem.

35 Thirteenth Report on the Draft Code of Crimes Against the Peace and Security of Mankind, by Mr. Doudou Thiam, Special Rapporteur, A/CN.4/466, 'Yearbook of International Law Commission' 1995, vol. II (1).

36 Draft code of crimes against the peace and security of mankind, 'Yearbook of International Law Commission' 1996, vol. II, Part Two, pp. 17-56. 
a part of the population; (g) arbitrary deportation or forcible transfer of a population; (h) arbitrary imprisonment; (i) forced disappearance of persons; (j) rape, enforced prostitution and other forms of sexual abuse; (k) other inhumane acts which severely damage physical or mental integrity, health or human dignity, such as mutilation and severe bodily harm. ${ }^{37}$

\subsection{Works of the International Law Commission on the statute of the International Criminal Court}

With the continuation of work on the draft Code, since the 1980s, the International Law Commission has addressed the implementation of the Code, thus initiating a discussion on the creation of a permanent International Criminal Court. ${ }^{38}$ Until 1990, the Commission discussed primarily the principle of aut dedere aut iudicare and the related competence of national courts to hear cases of crimes covered by the draft Code. In 1990, the Special Rapporteur, Doudou Thiam, presented the eighth report on the Draft Code of Crimes Against the Peace and Security of Mankind, which in the third part raised the problem of the statute of the International Criminal Court. ${ }^{39}$ The report addressed general issues regarding court jurisdiction, as well as procedural and organisational issues. The Special Rapporteur proposed that the jurisdiction of the future criminal court should cover not only the crimes specified in the draft Code, but also other crimes considered to be crimes in other international instruments in force ${ }^{40}$. According to Doudou Thiama, the concept of international crime is wider than the concept of crimes against the peace and security of mankind and includes other acts. As an example, the Special Rapporteur indicated: the dissemination of false or distorted news, or false documents, with the intention of adversely affecting international relations; insults to a foreign State; the counterfeiting of currency practised by one State to the detriment of another State, and the theft of national or archaeological

$37 \quad$ Ibidem, p. 32.

38 'Yearbook of International Law Commission' 1983, vol. II, Part One, A/CN.4/364

39 Eighth report on the Draft Code of Crimes Against the Peace and Security of Mankind by Mr. Doudou Thiam, Special Rapporteur, 'Yearbook of the International Law Commission' 1990, vol. II (1).

40 'Yearbook of International Law Commission' 1990, vol. II, Part One, A/CN.4/ SER.A/1990/Ad.1 (part 1), p. 36. 
treasures; the destruction of submarine cables; and international trafficking in obscene publications. ${ }^{41}$

The jurisdiction of the future criminal court was the subject of subsequent reports by the Special Rapporteur, presented between 1991 and 1993. It is worth noting that in the Tenth Report, a proposal was made for a detailed definition of the jurisdiction of the future criminal court, and amongst the crimes under the jurisdiction of this court, the Special Rapporteur included "mass violations of human rights". ${ }^{42}$ The Special Rapporteur's proposal therefore did not use the term crimes against humanity, which reflected the state of work on the Draft Code of Crimes Against the Peace and Security of Mankind. The concept of systematic or mass violations of human rights has been criticised by the Commission, and consequently the Special Rapporteur, in the subsequent Eleventh Report, resigned from formulating a catalogue of crimes within the jurisdiction of the court. ${ }^{43}$ The substantive jurisdiction of a future court has been determined by reference to agreements between states which will be bound by the statute of the court. This solution was based on the pre-war proposal prepared by V.V. Pella on the establishment of a criminal chamber of the Permanent Court of International Justice. ${ }^{44}$

The Eleventh Report of the Special Rapporteur has become, among others, in addition to the remarks made by countries with international jurisdiction in criminal matters and the UN Secretary-General's report on the creation of the International Criminal Tribunal for the former Yugoslavia, the work of the Working Group set up by the International Law Commission in May 1993. The Working Group proposed that the subject of the jurisdiction of the future International Criminal Court should include two-fold crimes. ${ }^{45}$ To the first category, the Working Group counted those crimes that met two criteria: 1) they were defined in international agreements in such a way that an international tribunal could apply these instruments; 2) in accordance with the treaty, their prosecution is

41 Ibidem.

42 'Yearbook of International Law Commission' 1992, vol. II, Part One, A/CN.4/ SER.A/1992/Ad.1 (part 1), p. 55.

43 'Yearbook of International Law Commission' 1992, vol. II, Part One, A/CN.4/ SER.A/1992/Ad.1 (part 1), p. 55.

44 United Nations War Crimes Commission, History of the United Nations War Crimes Commission and the development of the laws of war, p. 75.

45 Revised report of the Working Group on a draft statute for the International Criminal Court, Yearbook of the International Law Commission 1993, vol. II (2), p. 107. 
based on the principle of universal jurisdiction (aut dedere aut iudicare) or the treaty provides for the submission of this crime to the jurisdiction of an international tribunal. For these crimes, the Working Group counted, among others, genocide, grave breaches of the Geneva Conventions of 1949 and of the I Additional Protocol of 1977, or hostage taking. ${ }^{46}$ For obvious reasons, crimes against humanity could not be included in this category. To the second category, the Working Group included, among others, crimes of general international law accepted and recognised by the international community of states as a whole as being so fundamental that their violation involves the criminal liability of an individual. ${ }^{47}$ In this way, the proposal of the Working Group was intended to include the jurisdiction of an international crime tribunal that has its basis in international customary law. As an example of such crimes, the Working Group called out crimes against humanity, to the extent that they do not fall within the definition of genocide. The possibility of exercising jurisdiction by an international tribunal, however, has been limited by the need to notify, in writing, the secretary of the tribunal about the special consent to exercise jurisdiction. In addition, such consent could only be expressed by the state in whose territory the perpetrator would be present or in whose territory the crime would have been committed. ${ }^{48}$

The solution proposed by the Working Group has several drawbacks. First of all, some international crimes have a dual nature and result not only from treaty law but also from customary international law. This applies to genocide and grave breaches of the Geneva Conventions of 1949. Secondly, the reference to the norms recognised and accepted by the international community of the state is highly imprecise, because the project did not formulate any requirements of these offenses. This also raises legitimate concerns about compliance with the nullum crimen sine lege principle and leaves the international tribunal a considerable margin of discretion in deciding what is and what is not an international crime. The UN Security Council did not decide on such an operation, creating ad hoc criminal tribunals for the former Yugoslavia and for Rwanda.

The International Law Commission rejected the proposal of the Working Group for an exhaustive catalogue of crimes within the jurisdiction of the tribunal. In the $1994 \mathrm{draft}$ international statute of the criminal

\footnotetext{
46 Ibidem.

47 Ibidem, p. 110.

48 Ibidem.
} 
court, four categories of crimes were subject to the jurisdiction of the court, including crimes against humanity as a separate category from genocide and serious violation of the laws and customs of armed conflict (Article 20(d) of the draft statute). ${ }^{49}$ In Article 20 of the draft statute, however, there is no definition of these crimes. In the Commission's commentary to Article 20, reference is made to the charter of the International Military Tribunal, and the definition of crimes against humanity under Article 5 of the statute of the International Criminal Tribunal for the former Yugoslavia is cited. In the Commission's view, the essence of crimes against humanity is connected with inhuman acts of a very serious nature that involve large-scale or systematic violations aimed at the civilian population as a whole or in part. ${ }^{50}$

The draft statute of the International Criminal Court, including the provisions determining the jurisdiction of the court, was subject to further work within the UN General Assembly. Resolution 49/53 of 9.12.1994 created an ad hoc Committee for the International Criminal Tribunal. ${ }^{51}$ The Committee stressed the need to bring jurisdiction to the court of crimes against humanity because of their serious nature, but at the same time pointed to the difficulties involved in defining these crimes. ${ }^{52}$ As a starting point for the development of such a definition, the Committee proposed the charters of the International Military Tribunal and the International Military Tribunal for the Far East, Law no. 10 of the Allied Control Council and statutes of ad hoc criminal tribunals for the former Yugoslavia and Rwanda. The Committee stressed the need to include in the future definition of crimes against humanity the requirement to commit these crimes against any civilian population and to accentuate a large-scale or systematic attack. ${ }^{53}$ The list of acts that constitute crimes against humanity also raised doubts. While some delegates were in favour of a closed catalogue of deeds, others pointed to the need to introduce an open category in the form of so-called other inhumane acts. Some members of the Committee also drew attention

49 Report of the International Law Commission on the work of its forty-sixth session, 2.5.-22.7.1994, 'Yearbook of the International Law Commission' 1994, vol. II (2), pp. 36-37.

$50 \quad$ Ibidem, p. 38.

51 General Assembly Resolution 49/53 of 9.12.1994.

52 Report of the Ad Hoc Committee on the Establishment of an International Criminal Court, General Assembly Official Records, Fiftieth Session Supplement No. 22 (A/50/22), paras. 77-80.

53 Ibidem, para. 78. 
to the unclear understanding of the crime of persecution and demanded that this act be excluded from the catalogue of crimes against humanity. ${ }^{54}$ The issue of committing crimes against humanity in peacetime was also discussed. $^{55}$

The findings made by the ad hoc Committee were used for further work by the Preparatory Committee established by the General Assembly of the United Nations by Resolution 50/46 of 11.12.1995. ${ }^{56}$ Delegates from the Preparatory Committee had no doubts about the need to include crimes against humanity within the jurisdiction of the International Criminal Tribunal. ${ }^{57}$ The view was generally accepted that the definitions of crimes should be clear, precise and in full compliance with the principle of legality (nullum crimen, nulla poena sine lege), although the procedural nature of the statute of the International Criminal Tribunal was emphasised. ${ }^{58}$ In the absence of a generally accepted definition of crimes against humanity in the treaty law, the Preparatory Committee drew attention to the need to appeal to international customary law and international instruments, such as the charters of the International Military Tribunal and the International Military Tribunal for the Far East, Law No. 10 of the Allied Control Council, statutes of ad hoc criminal tribunals for the former Yugoslavia and for Rwanda, and the Draft Code of Crime Against the Peace and Security of Mankind developed by the International Law Commission. ${ }^{59}$

The Preparatory Committee underlined the paramount importance of the general features of crimes against humanity, which allow them to be distinguished from common crimes penalised by national law and subject to national jurisdiction. ${ }^{60}$ Two features of crimes against humanity were generally accepted by delegates of states, i.e. widespread or systematic attack and directing the attack against any civilian population.The controversial statements contained in the statute of the International Criminal

54

55

56

57 Report of the Preparatory Committee on the Establishment of an International Criminal Court, Volume I (Proceedings of the Preparatory Committee during March-April and August 1996), General Assembly Official Records · Fifty-first Session Supplement No. 22 (A/51/22), para. 51.

58 Ibidem, para. 52.

59 Ibidem, para. 83.

60 Ibidem, para. 84. 
Tribunal for Rwanda turned out to be wording referring to the motivation of the perpetrator and was expressed in the statute of the International Criminal Tribunal for the former Yugoslavia linking crimes against humanity with armed conflict.

Finally, the statute of the International Criminal Court, adopted at the conference in Rome on 17.7.1998, contained in Article 7 a general requirements of crimes against humanity and underlying offences. In addition, help for the Court in the interpretation and application of Article 7 came in the form of the Elements of the Crimes, adopted by the Assembly of States Parties on the basis of Article 9 of the ICC Statute. ${ }^{61}$

\section{The scope of the draft articles on the prevention and punishment of crimes against humanity}

The International Law Commission pointed to four issues to be covered by the draft articles: 1) definition of crimes against humanity; 2) the obligation of states to criminalise such crimes in domestic law, not only with regard to acts committed by their citizens or acts committed in their territory, but also with regard to acts committed by non-citizens abroad who then moved to the state (universal jurisdiction); 3) the obligation of states to cooperate in the investigation, prosecution and punishment of these offences, including mutual legal assistance, extradition and recognition of evidence; 4) the duty of aut dedere aut judicare fortified by the perpetrator's stay in the territory of the state party. ${ }^{62}$ The structure of the future convention regarding crimes against humanity has therefore been based on the existing conventions, which concern the prevention and punishment of the crime of genocide, apartheid or torture.

Special Rapporteur Sean D. Murphy has so far presented four reports on the articles on the prevention and punishment of crimes against humanity. The first report concerned the prevention and punishment of crimes against

61 Elements of Crimes, Official Records of the Assembly of State Parties to the Rome Statute of the International Criminal Court, First session, New York, 3-10.10.2002 (United Nations publication, Sales No. E.03.V.2 and corrigendum), Part II. B.

62 Report of the International Law Commission, Sixty-fifth session (6.5.-7.6.2013 and 8.7.-9.8.2013), 'Yearbook of the International Law Commission' 2013, vol. II (2), p. 142. 
humanity and the definition of these crimes. ${ }^{63}$ The second report, submitted to the International Law Commission in 2016, presented issues related to the criminalisation of crimes against humanity in domestic law and the exercise of national jurisdiction, as well as the principle of aut dedere aut iudicare. ${ }^{64}$ The subject of the third report was the extradition of people suspected of crimes against humanity and the provision of legal assistance in these crimes, the principle of non-refoulement, protection of victims and witnesses, the relation of draft articles to International Criminal Tribunals, mechanisms monitoring the implementation of the future convention and the final clauses of the future convention. ${ }^{65}$ The fourth report, issued after adoption the draft articles and commentaries in the first reading, was dedicated to the description of the comments and observations of States and international organizations. Besides Special Rapporteur presented its recommendation for the final form of the draft articles and indicated its suggestions to the draft articles adopted on first reading. ${ }^{66}$

The work of the International Law Commission on the articles on the prevention and punishment of crimes against humanity proceeded quite quickly. In 2015, the Commission adopted the first four draft articles with commentary. At its meeting in 2016, the Commission accepted a further six provisions with commentary, and in 2017, it adopted, on first reading, the entire set of draft articles together with commentaries thereto. Commisssion also decided to transmit the draft articles to governments and international organizations for comments and observations. During 2019 the Commission adopted, on second reading, the entire set of draft articles on prevention and punishment of crimes against humanity, comprising a draft preambule, together with commentaries thereto. The Commission also recommended the draft articles on prevention and punishment of crimes against humanity to the General Assembly and

63 First Report on Crimes Against Humanity, International Law Commission, Geneva, 17.2.2015, A/CN.4/680.

${ }^{64}$ Second Report on Crimes Against Humanity, International Law Commission, Geneva, 21.1.2016, A/CN.4/690.

65 Third Report on Crimes Against Humanity, International Law Commission, Geneva, 23.1.2017, A/CN.4/704.

66 Fourth Report on Crimes Against Humanity, International Law Commission, Geneva, 18.2.2019, A/CN.4/725. 
recommended the elaboration of a convention by the General Assembly or by an international conference of plenipotentiaries. ${ }^{67}$

\subsection{Definition of crimes against humanity}

The basic problem faced by the International Law Commission was the lack of a unified understanding of crimes against humanity. The most commonly adopted definition is formulated in Article 7 of the ICC Statute, which reflects the agreement reached between now 123 state parties. In light of this regulation, crimes against humanity are any of the following acts when committed as part of a widespread or systematic attack directed against any civilian population, with knowledge of the attack: (a) murder; (b) extermination; (c) enslavement; (d) deportation or forcible transfer of the population; (e) imprisonment or other severe deprivation of physical liberty in violation of fundamental rules of international law; (f) torture; (g) rape, sexual slavery, enforced prostitution, forced pregnancy, enforced sterilisation or any other form of sexual violence of comparable gravity; (h) persecution against any identifiable group or collective on political, racial, national, ethnic, cultural, religious, gender, as defined in paragraph 3 , or other grounds that are universally recognised as impermissible under international law, in connection with any act referred to in this paragraph or any crime within the jurisdiction of the Court; (i) enforced disappearance of persons; ( $\mathrm{j}$ ) the crime of apartheid; (k) other inhumane acts of a similar character intentionally causing great suffering or serious injury to the body or to mental or physical health.

Chronologically, the first statute of the International Criminal Tribunal for the former Yugoslavia, in Article 5, formulates the requirement of committing crimes against humanity during armed conflict, regardless of whether the conflict was of an international or internal nature. ${ }^{68}$ Article 3 of the statute of the International Criminal Tribunal for Rwanda determines criminal responsibility against the specific motivation of the perpetrator, i.e. committing crimes against humanity

67 Report of the International Law Commission Seventy-first session, 29.4-7.6.2019 and 8.7-9.8.2019, Yearbook of the International Law Commission 2019, ch. IV, para. 42.

68 W.J. Fenrick, The Crime Against Humanity of Persecution in the Jurisprudence of The ICTY, "Netherlands Yearbook of International Law" 2001, vol. XXXII, p. 85. 
for national, political, ethnic, racial or religious reasons. ${ }^{69}$ Interestingly, ICTR statutes do not expressis verbis state that the perpetrator's behaviour must be committed as part of a widespread or systematic attack. Both these definitions have become the basis for understanding crimes against humanity in the Statute of the Special Court for Sierra Leone (Article 2 of the SSSL Statute). The definition of crimes against humanity contained in Article 7 of the ICC Statute refer, however, to the agreement of 6.6.2003 between the United Nations and the Cambodian Royal Government on the prosecution of crimes committed in the Democratic Kampuchea period and Regulation 2000/15 of the international administration in Timor-Leste establishing a special panel of judges at the District Court in Dili. ${ }^{70}$ It should be pointed out that there is some inaccuracy between the agreement of 6.6.2003 and its implementation in Cambodian law by the law establishing emergency chambers in the Cambodian courts. ${ }^{71}$ Article 5 of this Act does not explicitly repeat Article 7 of the ICC Statute, as it does not refer to a state or organisational policy involving crimes against humanity, and - like the statute of the International Criminal Court for Rwanda - it determines criminal responsibility for committing crimes against humanity for national, political, ethnic, racial or religious reasons. ${ }^{72}$

Considering the broad support for the definition of crimes against humanity adopted in the ICC Statute and its complementary character, the International Law Commission adopted the definition of Article 7 of the ICC Statute, introducing three insignificant, linguistic amendments. ${ }^{73}$

Crimes against humanity within the meaning of the design of articles do not have the character of a crime of international law per se and consist

69 A. Szpak, Zbrodnie wojenne a zbrodnie przeciwko ludzkości w orzecznictwie międzynarodowych trybunatów karnych ad hoc (kryteria różnicowania) [War crimes and crimes against humanity in the jurisprudence of international ad hoc criminal tribunals (differentiation criteria)], "Państwo i Prawo" 2012, no. 1, p. 79.

70 Regulation 2000/15 on the establishment of Panels with exclusive jurisdiction over serious criminal offences, 6.6.2000, UNTAET/REG/2000/15.

${ }^{71}$ Law on the establishment of extraordinary chambers in the courts of Cambodia for the prosecution of crimes committed during the period of Democratic Kampuchea, 27.10.2004, NS/RKM/1004/006.

72 S. Ford, Crimes Against Humanity at the Extraordinary Chambers in the Court of Cambodia: Is a Connection with Armed Conflict Required?, "UCLA Pacific Basin Law Journal" 2007, vol. 24, pp. 127-128.

73 Report of the International Law Commission, Sixty-seventh session (4.5-5.6.2015 and 6.7-7.8.2015), Yearbook of the International Law Commission 2015, vol. II, Part Two, pp. $59-60$. 
of general requirements (so-called chapeau elements) and acts that constitute crimes. ${ }^{74}$ It should be emphasised that the act itself is not yet a crime against humanity, and if general indications are not met, this act will constitute a common crime subject to the jurisdiction of national judicial authorities. Rape or murder will be a common crime falling within the jurisdiction of a national court until it is part of a widespread or systematic attack against any civilian population. The Commission pointed to three general requirements (so-called chapeau elements) that constitute crimes against humanity: 1) widespread or systematic attack, 2) against any civilian population, and 3) committing crimes against humanity as part of state policy or organisational policy. ${ }^{75}$

In addition to the subject matter, the proposal of the International Law Commission also includes a subjective sign. The perpetrator of crimes against humanity should act with the awareness of committing such an act, as well as with the awareness that the act is part of a widespread or systematic attack against any civilian population. ${ }^{76}$ The International Law Commission, however, did not decide, based on the ICC Statute, to define the subjective sign precisely, and in the commentary on this draft Article, it appealed primarily to the adjudication of international ad hoc criminal tribunals. This may give rise to some difficulties in interpretation. In the jurisprudence of International Criminal Courts, the concept of general intention has emerged. ${ }^{77}$ The first judgments of the International Criminal Court also allowed for the possibility of committing crimes against humanity with a result intended. ${ }^{78}$ In view of the ambiguities resulting from the case law of international courts, the Commission should clarify the subject of crimes against humanity.

The Draft Articles of the International Law Commission emphasise that crimes against humanity are crimes of international law, irrespective

74 G. Boas, J.L. Bischoff, N.L. Reid, Elements of Crimes under International Law. International Criminal Law Practitioner Library Series, vol. II, Cambridge University Press, Cambridge 2008, p. 16.

75 Report of the International Law Commission, Sixty-seventh session (4.5-5.6.2015 and 6.7-7.8.2015), 'Yearbook of the International Law Commission' 2015, vol. II, Part Two, pp. 60-70.

76 Ibidem, p. 71.

77 The Prosecutor v. T. Blaškić, ICTY T.Ch., Judgement of 3.3.2000, IT-95-14-T, paras. 251-254.

78 The Prosecutor v. L. Dyilo, Decision on the Confirmation of Charges, 29.1.2007, ICC-01/04-01/6-803tEN, para. 351. 
of whether they were committed during armed conflict or peace (Article 2). ${ }^{79}$ In this way, the Commission accepted the view (uniformly expressed in the jurisprudence of international and hybrid criminal tribunals) that the commission of these crimes during the armed conflict is not included into general requirement of crimes against humanity. ${ }^{80}$ Undoubtedly, in most cases, crimes against humanity committed at the time of armed conflicts are not international, but the existence of such a conflict (or even an international military conflict) is not a condition that constitutes crimes against humanity.

\subsection{Forms of perpetration of crimes against humanity}

The rule nullum crimen sine lege shows that international criminal responsibility for crimes against humanity includes anyone who participated in this crime in the manner prescribed by law. As the Appellate Chamber of the ICTY in the D. Tadic case noted, the criminal tribunal includes its jurisdiction over all those who are responsible for serious violations of international humanitarian law committed on the territory of the former Socialist Federal Republic of Yugoslavia. Criminal liability applies not only to persons who have personally committed one of the international crimes, but also to others involved in crimes and indirect perpetrators. ${ }^{81}$ Hence, an extremely important and complicated issue during the work of the International Law Commission turned out to be the specification of the forms of responsibility for crimes against humanity.

The most basic form is the criminal liability of the person who commits the crime alone or in combination with other people. In the first case, the person independently carries out all the requirements of crime. In a situation where a crime is committed by several people, criminal

79 Report of the International Law Commission, Sixty-seventh session (4.5-5.6.2015 and 6.7-7.8.2015), 'Yearbook of the International Law Commission' 2015, vol. II, Part Two, p. 56 .

80 The Prosecutor v. T. Blaškić, ICTY T.Ch., Judgement of 3.3.2000, IT-95-14-T, para. 66; The Prosecutor v. M. Fofana, A. Kondewa, SCSL T.Ch., Judgement of 2.8.2007, SCSL04-14-T, para. 111, Extraordinary Chambers in the Courts of Cambodia, Guek Eav Kaing alias Duch, Judgment of 29.7.2010, 001/18-07-2007ECCC/TC, para. 291.

81 The Prosecutor v. D. Tadić, ICTY T.Ch., Judgment of 15.7.1999, IT-94-1-T, paras. 189-190; see also: The Prosecutor v. J.-P. Akayesu, ICTR T.Ch., Judgment of 2.9.1998, ICTR-96-4-T, paras. 471-479. 
liability is borne not only by the perpetrators, each of whom carries all the attributes of crimes against humanity, but also by people who - being accomplices - have significantly facilitated the commission of crimes against humanity, e.g. they encourage the perpetrator to committing this crime. This form of perpetration of crimes against humanity does not raise any doubts, both in the sphere of international and national law. Art. VI of the IMT Charter already provided for the criminal liability "of a person who, acting [...] personally, [...] committed any of the offenses listed below". According to Principle I, developed by the International Law Commission on the "Principles of International Law Recognised in the Charter of the Nürnberg Tribunal and in the Judgment of the Tribunal", a person who commits crimes against humanity is responsible for this and is punishable ${ }^{82}$. The criminal liability of the direct perpetrator was also recorded in the statutes of all subsequent international and hybrid criminal tribunals, and above all in Article 25(2) and (3) of the ICC Statute ${ }^{83}$. The direct perpetration of crimes against humanity is also penalised by the vast majority of countries in the world. ${ }^{84}$

The International Law Commission also pointed to the need to criminalise other forms of perpetration of crimes against humanity that are in addition to committing crimes in domestic law. The Commission listed the following forms: ordering, soliciting, inducing, aiding, abetting, otherwise assisting in or contributing to the commission or attempted commission of such a crime. ${ }^{85}$ In the context of statutes of international and hybrid criminal tribunals, it should be noted that the above calculation of forms of committing crimes against humanity is a peculiar combination of various legal institutions. For example, the statutes of the ICTY, ICTR and SSSL (Article 7, 6 and 5, respectively) mention the following forms: planning, instigating, ordering, committing, aided and abetted in

82 Principles of International Law recognised in the Charter of the Nuremberg Tribunal and in the Judgment of the Tribunal, 'Yearbook of the International Law Commission' 1950, vol. II, p. 374.

83 Article 7(1) ICTJ Statute, Article 6(1) ICTR Statute, Article 6(1) SCSL Statute, section 5 UNTAET regulation 2000/15, Article 5 The law establishing Extraordinary Chambers in Cambodian courts, Article 10 letter b Special Tribunal for Iraq Statute.

84 Second Report on Crimes Against Humanity by Sean D. Murphy, Special Rapporteur, 21.1.2016.

85 Report of the International Law Commission, Sixty-seventh session (4.5-5.6.2015 and 6.7-7.8.2015), 'Yearbook of the International Law Commission' 2015, vol. II, Part Two, p. 244. 
the planning, preparation or execution. However, in accordance with Article 25(3) of the ICC Statute, following acts shall be punishable: committing, ordering, soliciting, inducing, aiding, abetting, otherwise assists in its commission or its attempted commission or in any other way contributing to the commission or attempted commission of such a crime by a group of persons acting with a common purpose. A similar catalogue of forms of perpetration of a crime is provided in section 14.3 of UNTAET Regulation 2000/15 establishing special panels for East Timor.

The commentary of the International Law Commission to the draft Article 5 follows, however, that the purpose of this provision is not to rigidly determine the forms of perpetrating crimes against humanity and the indication of general legal institutions. ${ }^{86}$ Such a procedure will allow states to transfer these general institutions to their own legal orders, taking into account the regulations in force in these countries regarding the forms of committing crimes, judicial decisions and legal traditions. Justifying its position, the International Law Commission recalled the 2006 Convention on the Protection of All Persons from Enforced Disappearances. ${ }^{87}$ This Convention states in Article 6 that "Each State Party shall take the necessary measures to hold criminally responsible at least ... [any] person who commits, orders, solicits or induces the commission of, attempts to commit, is an accomplice to or participates in an enforced disappearance".

Among the forms of committing crimes against humanity, the International Law Commission also mentioned attempting to commit a crime. This is a novelty in relation to the legal situation in force. International law does not recognise a universal treaty norm providing for criminal responsibility for attempting crimes against humanity, with the exception of the ICC Statute and the 1948 Convention on the prevention and punishment of the crimes of genocide. By introducing a responsibility for the attempt into the Draft Articles, the Commission stressed the contemporary tendency in international law to recognise the punishability of this form. This is connected not only with the hardships that ad hoc criminal tribunals caused in criminal proceedings against

86 Report of the International Law Commission, Sixty-seventh session (4.5-5.6.2015 and 6.7-7.8.2015), 'Yearbook of the International Law Commission' 2015, vol. II, Part Two, p. 254.

87 International Convention for the Protection of All Persons from Enforced Disappearance, 20.12.2006, UNTS vol. 2716, p. 3. 
crimes against humanity, but also the closeness of this form of committing crimes to actual crimes. The ratio legis of punishing of attempts is related with the fact the perpetrator externalises its behaviour which is indirectly aimed at attacking the legal, protected values. ${ }^{88}$

\subsection{The extent of obligations of states related to prevention and punishment of crimes against humanity}

The works of the International Law Commission are focused on the obligations of countries related to prevention and punishment of crimes against humanity. The prevention of these crimes involves taking action to prevent the commission of such crimes. ${ }^{89}$ Duties related to the punishment of crimes are updated during or after the commission of a crime and concern the criminal proceedings which the state should conduct against a suspect. ${ }^{90}$ In the case of prevention as well as punishment, states are obliged to take action in their national legal orders and to cooperate with other states and with international intergovernmental organisations (article 4(1) Draft Articles). Obligations resulting from the design of the Articles are therefore essentially horizontal.

A strict separation of duties related to punishing crimes against humanity and duties related to prevention is not possible. These are closely related and overlap. Therefore, specific solutions adopted in the Draft Articles will be discussed below.

\subsubsection{The obligation to criminalise crimes against humanity}

Under the influence of the ICC Statute, many states have criminalised, in national law, behaviours considered as crimes against humanity. ${ }^{91}$ In many countries, however, these crimes are not considered actual crimes. In view of the multiplicity of definitions of crimes against humanity at

88 K. Buchała, A. Zoll, Polskie prawo karne [Polish Criminal Law], Wydawnictwo Prawnicze PWN, Kraków 1997, p. 281.

89 Report of the International Law Commission, Sixty-seventh session (4.5-5.6.2015 and 6.7-7.8.2015), 'Yearbook of the International Law Commission' 2015, vol. II (2), p. 52.

90 Ibidem.

91 Report of the International Law Commission, Sixty-seventh session (2.5-10.6.2016 and 4.7-12.8.2016), 'Yearbook of the International Law Commission' 2016, vol. II (2), p. 248. 
the international level, the countries are inconsistent with understanding to this crime in their internal legal orders. Thus, in Article 5 of the Draft Articles, states are obliged to take the necessary measures to criminalise crimes against humanity in their legal systems, as understood by the design of articles, and to introduce strict penalties for their commission. Unification of the understanding of crimes against humanity and the forms of their committing in state legislations should result in the impunity of criminals being reduced. Even after the entry into force of the Draft Articles of the International Law Commission, the convention will not be self-enforceable and can not be directly applied.

The Draft Articles do not impose on states the amount of penalties that should be imposed for crimes against humanity. The International Law Commission emphasised, however, that these should be punishments appropriate to the grave nature of these crimes. ${ }^{92}$ Analysing the cases of people convicted of crimes against humanity, as recognised before international and hybrid criminal tribunals, it is impossible not to notice the large range of penalties imposed by these courts on persons guilty of committing crimes against humanity. This is due to the fact that the statutes of these criminal tribunals do not set the upper and lower limits for the penalty of deprivation of liberty, indicating only the general circumstances that should be taken into account when determining the penalty.

Judicial practice shows that the most important factor which criminal tribunals take into account when determining the sentence for crimes against humanity is the weight of these crimes. ${ }^{93}$ As noted by the International Criminal Tribunal for Rwanda in the Nahimany case, longer sentences remain reserved for the most serious crimes, and crimes against humanity should be treated as one of the most serious and gravest crimes deserving severe punishment. ${ }^{94}$ In the Erdemović case, the International Criminal Tribunal for the former Yugoslavia stated that crimes against humanity are characterised by a greater burden than war crimes and

92 Ibidem, p. 260.

93 The Prosecutor v. J.-P. Akayesu, ICTR A.Ch., Judgment of 1.6.2001, ICTR-96-4-A, para. 413, The Prosecutor v. F. Nahimana, ICTR A.Ch., Judgment of 28.11.2007, ICTR-9952-A, para. 1060, The Prosecutor v. Z. Delalić, Z. Mucić, H. Delić, E. Landžo, ICTY A.Ch., Judgment of 20.2.2001, IT-96-21-A, para. 731, The Prosecutor v. B. Plavsić, ICTY T.Ch., Judgement and Sentence of 27.2.2003, IT-00-39 \& 40/1, para. 25.

94 The Prosecutor v. F. Nahimana, ICTR A.Ch., Judgment of 28.11.2007, ICTR-99-52-A, para. 1060. 
therefore deserve a more severe punishment, even if the conviction for both these crimes is based on the same facts. ${ }^{95}$ Crimes against humanity are directed not only against a particular person subject to protection, but against the whole human race and constitute a particularly repulsive form of attack on human dignity. ${ }^{96}$ Crimes against humanity are not isolated or sporadic behaviour, but are part of a wider pattern of violence against a particular group of civilians. ${ }^{97}$

International jurisprudence shows that punishments for crimes against humanity are stricter than those imposed for war crimes. P. Akhavan notes that the average length of imprisonment for genocide exceeds 40 years, while for crimes against humanity, it is around 16 years. ${ }^{98}$ However, these values are averaged, and in specific cases, the range of penalties imposed for crimes against humanity is high. For example, Kaing Guek Eav was convicted of crimes against humanity by the Cambodian Tribunal and sentenced to life imprisonment. ${ }^{99}$ The Special Court for Sierra Leone punished Charles Taylor for crimes against humanity with a penalty of 50 years imprisonment, and Moinine Fofanie - 15 years imprisonment. Such a severe penalty of imprisonment against Charles Taylor SCSL was justified, above all, due to the fact that he was the president of Liberia and was a regional political leader. ${ }^{100}$

It is worth noting that domestic courts treat the perpetrators of crimes against humanity equally severely; however, in the judgments of these courts, a large range of punishments can also be seen. After 1990, domestic courts dealt mainly with the settlement of crimes against humanity committed on the territory of the former Yugoslavia and Rwanda. Some of the cases were proceedings submitted to national jurisdiction by the International Criminal Tribunal for the former Yugoslavia and the International Criminal Tribunal for Rwanda. Cases communicated by the International Criminal Tribunal for the former Yugoslavia were

95 Prosecutor v. D. Erdemović, ICTY A.Ch., Judgment of 7.10.1997, Joint Separate Opinion of Judge McDonald and Judge Vohrah, IT-96-22-A, para. 20.

96 Ibidem, para. 21.

97 Ibidem, para. 22.

98 P. Akhavan, Reducing Genocide to Law. Definition, Meaning, and the Ultimate Crime, Cambridge University Press, Cambridge 2015, p. 66.

99 Extraordinary Chambers in the Courts of Cambodia, Guek Eav Kaing alias Duch, Judgment of 3.2.2012, 001/18-07-2007-ECCC/SC, p. 320.

100 The Prosecutor v. Ch. Taylor, SCSL T.Ch., Judgment of 26.4.2012, SCSL-03-01-I, paras. 96-103. 
recognised by the courts of Bosnia and Herzegovina and the courts of the Republic of Croatia, and cases referred by the International Criminal Tribunal for Rwanda - by the Rwandan and French courts.

From the cases handed over to the Bosnian courts, the proceedings in the case of Radovan Stankovic ended with allegations of the rape of women and girls aged 12-14 and other crimes against humanity committed in the Bosnian city of Foča in 1992. The court found him guilty of all crimes, and he was charged and punished with 20 years imprisonment. ${ }^{101}$ Before the Bosnian court, there were also proceedings against Dušan Fuštar, commander of guards at the Keraterm camp in Prijedor. In this camp, there were numerous situations in which prisoners were beaten and killed in a cruel manner, and some prisoners were sexually assaulted. In addition, prisoners were held in inhumane conditions. Dušan Fuštar was found guilty of committing crimes against humanity in the conditions of a joint criminal enterprise and was sentenced to 9 years imprisonment. ${ }^{102}$ Other Yugoslav criminals who were accused of committing, among others, crimes against humanity in the Keraterm and Omarska camps were Momčilo Gruban, Željko Mejakić and Duško Knezević. None of them pleaded guilty and did not use the right to conclude an agreement regarding the amount of the penalty with the prosecutor. Duško Knezević was sentenced to 31 years imprisonment, Željko Mejakić - 21 years imprisonment, Momčilo Gruban - 11 prison sentences. ${ }^{103}$

Before the Croatian courts, allegations of committing crimes against humanity were made against Rahim Ademi and Mirko Noraci. Rahim Ademi, from 1992, served as the chief of staff in the Gospić military district. Mirko Norać was the commander of the brigade of the Croatian Army. They were accused of participating in the persecution of the Serbian population, during which homicides and inhuman acts were performed, such as shooting at civilians, cutting off limbs or beatings. Rahim Ademi was acquitted of all charges against him. Mirko Norać, on the other hand, was found guilty of committing crimes against humanity related to participation in the mass murders of the population in Gospić and sentenced to 6 years imprisonment.

Sud Bosne and Hercegovine, no X-KRŽ-05/70, Sarajevo, Judgement of 28.3.2007.

102 Sud Bosne and Hercegovine, no X-KRŽ-06/200-1, Sarajevo, Judgement of 21.4.2008.

103 Sud Bosne and Hercegovine, no X-KRŽ-06/200, Sarajevo, Judgement of 16.2.2009. 
From among the cases handed over to national courts by the International Criminal Tribunal for Rwanda, only the criminal proceedings against Jean Uwinkindi were concluded. Other people are hiding from the justice system and have so far avoided punishment. Jean Uwikindi, during the genocide in Rwanda, was a pastor of the Pentecost church, located in the Nyamata district of Kanzeze in Kigali Prefecture, and belonged to the Hutu tribe. He was charged with genocide for directing the Hutu group, who exterminated about 2,000 Tutsi in the village of Kanzeze. The Rwandan court found him guilty of genocide and sentenced to life imprisonment.

Among the solutions proposed by the International Law Commission, it is worth paying attention to draft Article 5(5) and (7). ${ }^{104}$ The first of these provisions repeats the principle of non-commemoration of crimes against humanity, known from the 1968 Convention on nonuse of limitation of war crimes and crimes against humanity. This principle is of great practical importance. The institution of limitation detaches the relationship between the crime and the punishment due to the passage of time, which directly affects the possibility of a preventive impact of punishment on the perpetrator. Non-applicability of statute of limitations means that the International Law Commission and, in the future the State Parties to the Convention, consider it advisable to prosecute and punish the person guilty of the crimes against humanity regardless of the passage of time.

Article 5(7) of the draft introduces the state's commitment to introducing the liability of legal persons for crimes against humanity. However, this obligation is conditional and depends on whether the state introduces the legal responsibility of such entities in its legal order and whether it considers it appropriate to extend such liability to crimes against humanity. The International Law Commission also does not impose upon the states the nature of this responsibility, considering that it may take the form of criminal, civil or administrative liability. The formula used in this provision is therefore very flexible; on the one hand promoting the legal liability of legal persons for crimes against humanity, on the other hand leaving the states the choice of the most favourable formula to themselves.

104 Report of the International Law Commission, Sixty-seventh session (2.5-10.6.2016 and 4.7-12.8.2016), 'Yearbook of the International Law Commission' 2016, vol. II (2), p. 245. 


\subsubsection{The state's obligation to establish jurisdiction over perpetrators of crimes against humanity}

The rules for the exercise of criminal jurisdiction for crimes against humanity should be shaped in such a way that the national judicial authorities can take action against the widest possible list of persons suspected of crimes. The harmonisation of these principles in an international agreement should prevent a situation where no state can exercise jurisdiction. By establishing jurisdiction over the crime, the state equips itself with the necessary legal tools not only to prevent but, above all, to administer justice. ${ }^{105}$ In the draft Code of Crimes Against the Peace and Security of Mankind of 1996, the International Law Commission already wrote that each state should take all possible measures to establish its jurisdiction over these crimes, regardless of where or by whom the crimes were committed. ${ }^{106}$

Jurisdiction issues are taken into consideration in Article 6 of the Draft Articles. According to this provision, the basic rule is the principle of territoriality, according to which the state should exercise its jurisdiction over crimes against humanity committed in the territory under the jurisdiction of that state or on a seagoing vessel or aircraft registered to that state. The Commission thus encourages states to establish jurisdiction over crimes against humanity committed not only on its national territory, but also on the territory subject to its jurisdiction and under its effective control. ${ }^{107}$

Subsequent provisions of Article 6 of the project introduce the principle of active and passive personnel jurisdiction. ${ }^{108}$ The first of them is obligatory when the perpetrator of the crime is a citizen of the state exercising jurisdiction. On the other hand, if the crime was committed by a stateless person who is usually a resident in that state, and if the criminal citizen is a criminal offender, the establishment of jurisdiction is optional, since, according to the Commission, many states do not provide for this type of jurisdiction in their legislation.

105 Questions relating to the Obligation to Prosecute or Extradite (Belgium v. Senegal), Judgment, ICJ Reports 2012, p. 422, at p. 451, para. 75.

${ }_{106}$ Draft Code of Crimes Against the Peace and Security of Mankind with commentaries, 'Yearbook of the International Law Commission' 1996, vol. II (2), p. 28.

107 Report of the International Law Commission, Sixty-eight session (2.5-10.6.2016 and 4.7-12.8.2016), 'Yearbook of the International Law Commission' 2016, vol. II (2), p. 266.

108 Ibidem, p. 268. 
The Draft Articles establish universal jurisdiction for crimes against humanity. According to Article 6(2), universal jurisdiction is, however, subject to staying within the jurisdiction of that state and there is no decision to extradite or issue that person to another state. ${ }^{109}$ After fulfilling these two conditions, the state in the territory of which no crimes against humanity have been committed or whose citizen is not a perpetrator or victim of a crime is obliged to undertake actions aimed at judging and punishing the perpetrator.

\subsubsection{State obligations related to criminal proceedings}

The International Law Commission formulated a series of obligations of states with a procedural character in the Draft Articles. Committing a crime updates the state's obligation to conduct prompt and efficient criminal proceedings, the purpose of which is to explain all the circumstances of the crime and to punish the guilty person. Article 8 of the draft has fundamental importance from this perspective. This provision obliges the state to initiate and conduct a prompt and impartial investigation whenever there is reasonable ground to believe that acts constituting crimes against humanity have been or are being committed in any territory under the jurisdiction of the state. This obligation has featured in some treaties addressing other international crimes, especially in Article 12 of the 1984 Convention against torture and other cruel, inhuman or degrading treatment or punishment and in Article 8 of the 2006 International Convention for the Protection of All Persons from Enforced Disappearance $^{110}$. The requirement of promptness means that as soon as there is suspicion of a crime having been committed, investigations should be initiated immediately or without any delay. ${ }^{111}$ The requirement of impartiality means that states must proceed with their investigations in a serious, effective and unbiased manner.

\footnotetext{
109 Ibidem.

110 International Convention for the Protection of All Persons from Enforced Disappearance, 20.12.2006, UNTS vol. 2716, p. 3.

111 Report of the International Law Commission, Sixty-seventh session (1.5-2.6.2016 and 3.7-4.8.2016), 'Yearbook of the International Law Commission' 2017, vol. II (2), p. 80.
} 
The Draft Articles - following other current international conventions - introduces several specific responsibilities of states related to the investigation:

- obligation of a state, in the territory under whose jurisdiction a person alleged to have committed any crimes against humanity is present, to take that person into custody or to take other legal measures to ensure his or her presence. The custody and other legal measures shall be as provided in the law of that state but may be continued only for such time as is necessary to enable any criminal, extradition or surrender proceedings to be instituted (Article 9(1);

- making a preliminary inquiry into the facts (Article 9(2));

- aut dedere aut iudicare (Article 10);

- guarantees, at all stages of the proceedings, fair treatment, including a fair trial, and full protection of the individual's rights under applicable national and international law, including human rights law (Article 11);

- obligation to include crimes against humanity as an extraditable offence in any extradition treaty existing between states (Article 12);

- obligation to afford the widest measure of mutual legal assistance in investigations, prosecutions and judicial proceedings in relation to the crimes against humanity (Article 14).

\section{Ending}

The works of the International Law Commission on the Draft Articles on the prevention and punishment of crimes against humanity, apart from the ICC Statute, has great influence on the shape of both international and national criminal responsibility for these crimes. Based on ICC Statute, Draft Articles adopt statutory understanding of crimes against humanity. In the future that two international instruments may influence customary international law, and states which will not ratify these international treaties, will be bound by the definition of crimes against humanity stemming from Article 7 of the ICC Statute.

Draft Articles shows that crimes against humanity do not transform into new crimes called mass violation of human rights or into mass international crimes combining some acts of genocide and crimes against 
humanity. This would not only undermine the efforts to isolate both these crimes and to define the legal shape of each of them, but it would also obliterate the differences in the weight of these crimes. Crimes against humanity, because of the values they protect, and thus humanity as a whole and humanity understood as the essence of humanity, deserve to develop as a separate legal category from other crimes of international law.

\section{Bibliography}

1. Akhavan P., Reducing Genocide to Law. Definition, Meaning, and the Ultimate Crime, Cambridge University Press, Cambridge 2015

2. Akhavan P., The Universal Repression of Crimes Against Humanity before National Jurisdictions. The Need for a Treaty-Based Obligation to Prosecute, [in:] L.N. Sadat, 'Forging a Convention for Crimes Against Humanity', Cambridge University Press, Cambridge 2011

3. Bassiouni M. Cherif, International Criminal Law Third Edition, vol. II, Multilateral and Bilateral Enforcement Mechanisms, Brill, Leiden 2008

4. Boas G., Bischoff J.L., Reid N.L., Elements of Crimes under International Law. International Criminal Law Practitioner Library Series. vol. II, Cambridge University Press, Cambridge 2008

5. Buchała K., Zoll A., Polskie prawo karne, Wydawnictwo Prawnicze PWN, Kraków 1997

6. Fenrick W.J., The Crime Against Humanity of Persecution in the Jurisprudence of The ICTY, "Netherlands Yearbook of International Law" 2001, vol. XXXII

7. Ford S., Crimes Against Humanity at the Extraordinary Chambers in the Court of Cambodia: Is a Connection with Armed Conflict Required?, "UCLA Pacific Basin Law Journal" 2007, vol. 24

8. Ostropolski T., Zasada jurysdykcji uniwersalnej w prawie międzynarodowym, Instytut Wydawniczy Euro Prawo, Warszawa 2008

9. Sadat L.N., Forging a Convention for Crimes Against Humanity, Cambridge University Press, Cambridge 2011

10. Schindler D., Toman J., The Laws of Armed Conflicts, Martinus Nijhoff Publishers, Dordrecht 1988

11. Sluiter G., "Chapeau Elements" of Crimes Against Humanity in the Jurisprudence of the UN Ad Hoc Tribunals [in:] L. Sadat, 'Forging a Convention for Crimes Against Humanity', Cambridge University Press, Cambridge 2011

12. Stanton G.H., Why the World Needs an International Convention on Crimes Against Humanity, [in:] L.N. Sadat, 'Forging a Convention for Crimes Against Humanity', Cambridge University Press, Cambridge 2011 
13. Stigen J., The Relationship between the International Criminal Court and National Jurisdictions. The Principle of Complementarity, Martinus Nijhoff Publishers, Leiden 2008

14. Szpak A., Zbrodnie wojenne a zbrodnie przeciwko ludzkości w orzecznictwie międzynarodowych trybunatów karnych ad hoc (kryteria różnicowania), "Państwo i Prawo" 2012, no. 1

15. El Zeidy M.M., The Principle of Complementarity in International Criminal Law: Origin, Development and Practice, Brill, Leiden-Boston 2008 